Webology, Volume 16, Number 2, December, 2019

\begin{tabular}{|l|l|l|l|}
\hline Home & Table of Contents & Titles \& Subject Index & Authors Index \\
\hline
\end{tabular}

\title{
A Bibliometric Analysis and Visualization of the Scientific Publications of Universities: A Study of Hamadan University of Medical Sciences during 1992-2018
}

\section{Heidar Mokhtari}

Assistant Professor, Department of Library and Information Science, Payame Noor University, Tehran, Iran. ORCID: 0000-0002-2471-0408. E-mail: h.mokhtari@pnu.ac.ir

\section{Seyedeh Zahra Mirezati}

Student Research Committee, Hamadan University of Medical Sciences, Hamadan, Iran. ORCID: 0000-0001-8922-2731. E-mail: z.mirezati69@gmail.com

\section{Mohammad Karim Saberi}

Corresponding author, Assistant Professor, Department of Medical Library and Information Sciences, School of Paramedicine, Hamadan University of Medical Sciences, Hamadan, Iran. ORCID: 0000-0002-2471-0408. E-mail: m.saberi@umsha.ac.ir

\section{Farzaneh Fazli}

Ph.D., Library and Information Science, Hamadan University of Medical Sciences, Hamadan, Iran. ORCID: 0000-0003-3705-6422. E-mail: farzanehiri@ yahoo.com

\section{Mohammad Kharabati-Neshin}

M.Sc. Medical Library and Information Sciences, Hamadan University of Medical Sciences, Hamadan, Iran. ORCID: 0000-0002-0512-0840. E-mail: m.kharabati@gmail.com

Received September 25, 2019; Accepted December 20, 2019 


\section{Abstract}

The evaluation of universities from different perspectives is important for their scientific development. Analyzing the scientific papers of a university under the bibliometric approach is one main evaluative approach. The aim of this study was to conduct a bibliometric analysis and visualization of papers published by Hamadan University of Medical Science (HUMS), Iran, during 1992-2018. This study used bibliometric and visualization techniques. Scopus database was used for data collection. 3753 papers were retrieved by applying Affiliation Search in Scopus advanced search section. Excel and VOSviewer software packages were used for data analysis and bibliometric indicator extraction. An increasing trend was seen in the numbers of HUMS's published papers and received citations. The highest rate of collaboration in national level was with Tehran University of Medical Sciences. Internationally, HUMS's researchers had the highest collaboration with the authors from the United States, the United Kingdom and Switzerland, respectively. All highly-cited papers were published in high level Q1 journals. Term clustering demonstrated four main clusters: epidemiological studies, laboratory studies, pharmacological studies, and microbiological studies. The results of this study can be beneficial to the policy-makers of this university. In addition, researchers and bibliometricians can use this study as a pattern for studying and visualizing the bibliometric indicators of other universities and research institutions.

\section{Keywords}

Scientific publications; Bibliometric analysis; Visualization; Co-authorship

\section{Introduction}

One main criterion for determining the scientific placement of a country is the scientific publications produced by its universities and research institutes (Archambault et al., 2008). Publishing scientific papers is an inseparable part of the academic life (Chan et al., 2009) and the main output of scientific performance (Jacobson, 1997). Thousands of papers are annually published by researchers worldwide. They can be evaluated in different levels, including author, institution, country and subject levels.

Bibliometrics is a common way of evaluating scientific publications from different perspectives. Before coining the term "bibliometrics", Hulme (1923) used "statistical bibliography" in 1923. He defined statistical bibliography as a method for studying the science and technology history with counting documents and papers. In Aslib Annual Conference in UK in 1948, S. R. Ranganathan used the term "librametry" and explained its application (Sengupta, 1999). In 1969, Pritchard (1969) replaced the term statistical bibliography with the term bibliometrics and conceived it as the application of mathematics and statistical methods to books and other media 
of communication. In line with this definition, the British Standard Glossary of Documentation of Terms (1976) defined bibliometrics as studying the use of documents and publication patterns by applying mathematical and statistical methods (cf. Kannan \& Thanuskodi, 2019). Ackermann (2005) defined bibliometrics as the quantitative analysis of scientific texts (documents) based on publication and citation data. Bibliometrics depicts the scientific communications among authors, institutions and countries (Özkose \& Gencer, 2017). As a research field, it analyses the scientific publications, citations and references (Merigó et al., 2015). It is a tool for assessing the research state in a journal, field, research institution and country. It can bridge the possible gaps in scientific knowledge and demonstrate its trend and plays a main role in the management of / and decision-making on science and technology (Romanelli et al., 2018).

50 years after its emergence, bibliometrics is ever used for research evaluation. In the past, researchers used simple bibliometric analyses for journal papers, research fields, universities and institutes. In recent years, bibliometric analysis and visualization are simultaneously used as a mixed method for making better scientometric analyses. It appears that the traditional and simple bibliometric analyses are not enough for better mapping the scientific activity and some visualization is needed. Nowadays, many software packages have been designed for facilitating bibliometric analyses. As a new approach to bibliometric studies, this can be defined as "visualization of literature" or "visualization of information" (Milojevic, 2009).

Some scientific phenomena and communications are abstract and visualization tries to detect and depict such invisible notions in the structure of science in the form of a graphical multidimensional map. Visualization represents the importance or significance by using a size symbol (e.g. large symbols for main categories) or color (e.g. bright colors for low-important entities) (Synnestvedt \& Chen, 2005). In addition, it applies a threshold (e.g. a citation threshold for 50 authors with high citations) for determining the categories that appear in the map. In general, visualization is a powerful tool for studying the structure and dynamics of research publications. It is complementary to bibliometrics, helpful in doing better evaluation and analysis of the scientific output (Özkose et al., 2017; Noyons, 1999; Noyons, 2004; van Eck et al., 2010).

Each university or research institute should continuously monitor its past and present states for mapping its future perspectives. As one of Iranian known medical universities, the Hamadan University of Medical Sciences (HUMS), located in Hamadan province, Iran started its work in medicine, nursing and hygiene fields with the help of Université de Montpellie (UM). With 10 colleges, 17 research centers, 3 research institutes, one business incubator, one central and 12 branch and hospital libraries, HUMS is active in more than 98 disciplines in medical, paramedical and basic sciences in different educational levels. It has about 5886 students and 458 faculty members (HUMS, 2019). The first paper of the university indexed in Scopus belonged to 1992. After then, about 2000 papers of the university were indexed in Scopus. As a result, an allinclusive study needs to be conducted for analyzing all publications of HUMS. Such a study 
helps in identifying the past and present states of its research output as well as determining its weaknesses and strengths in the scientific performance. The results of this study can be beneficial to policy-makers of this university. In addition, this bibliometric and visualization study can be a pattern for analyzing the scientific performance of other universities and research institutes worldwide.

\section{Literature Review}

Bibliometrics is a main research field with a long history. After being coined, bibliomerics changed in a topic of interest and many researchers used bibiometric techniques. These studies are in four main categories: bibliometric analyses of research fields, scientific journals, publishing countries and regions, and universities and research institutes.

Some studies analyzed research fields such as RFID' publications (de Oliveira et al., 2019); tuberculosis (Nafade et al., 2018); IncRNA (Zhai et al., 2018); urban education (Liang \& Wang, 2018); environmental damage (Li et al., 2018); linguistics (Mohsen et al., 2017); information architecture (Taga et al., 2017); fuzzy research (Merigó et al., 2015); welding (Layus and Kah, 2015); computer science (Uddin et al., 2015); and entrepreneurship (Landström et al., 2012).

Other studies considered scientific journals such as Journal of Artificial Societies and Social Simulation (Mokhtari, Roumiyani \& Saberi, 2019); Sustainability (Tang et al., 2018a); Journal of Infection and Public Health (Krauskopf, 2018); Journal of Psychology (Tur-Porcar, 2018); Journal of Knowledge Management (Gaviria-Marin et al., 2018); Journal of Religion and Health (Şenel \& Demir, 2018); European Journal of Marketing (Martínez-López, 2018); International Journal of Fuzzy Systems (Tang et al., 2018); Journal of School Health (Zhang et al., 2017); European Journal of Operational Research (Laengle et al., 2017); Malaysian Journal of Library \& Information Science (Bakri \& Willett, 2017); Journal of Oral Research (Corrales-Reyes et al., 2016); and Electronic Library Journal (Hussain, Fatima \& Kumar, 2011).

The scientific publications of several regions and countries have been underwent bibliometric analyses, including among others Cuba (Corrales-Reyes et al. 2019); Iran (Chalak et al., 2018); Guatemala (Monge-Nájera \& Ho, 2018); Ghana (Osei Boamah \& Ho, 2018); Nicaragua (MongeNájera \& Ho, 2017); Czech (Fiala \& Ho, 2017); Spain (Bueno-Aguilera, et al, 2016); China (Jiang et al, 2014); Greek (Sachini et al., 2015); South America (Huamaní et al. 2014); Western Ghats (Saravanan, 2012); Africa (Chuang et al., 2011); South Africa (Kahn, 2011); Venezuela (Rojas-Sola \& Jorda-Albinana, 2010); and Brazill (Da Luz et al., 2008).

In some bibliometric researches, the scientific publications of research institutes and universities have been studied. Some recent studies on the topic were summarized as follows.

Ahmed et al. (2019) conducted a bibliometric study, entitled as "Bibliometric analysis of 
research publications of Al-Jouf University, Saudi Arabia, during the years 2006-2017". Using Scopus database, they found that the university published 801 papers in the studied years, with a considerable scientific growth during 2013-2017 when two-thirds of papers were published. The number of citations per paper was 4.53 with the highest citation rate amounted to 6.26 in 2016 . The highest rate of national collaboration was with King Abdulaziz University. Five hundred ninety-one papers $(73.78 \%)$ were authored with an international co-authorship pattern. Egypt (with 388 papers) and Malaysia (with 45 papers) ranked first and second in collaborating with the university, respectively. The most preferred journal for Al-Jouf University' authors was the International Medical Journal.

Darmadji et al. (2018) conducted a research under the title "Research productivity and international collaboration of top Indonesian universities" and identified top Indonesian universities' papers indexed in Scopus during 2001-2017. They found a significantly increased trend in the number of these papers during the studied period. The most prolific institute was the Bandung Institute of Technology with 7828 papers. Japanese researchers had the highest collaboration with co-authoring 3907 papers.

In a paper entitled as "Research productivity at King Saud bin Abdul Aziz University for Health Sciences, Kingdom of Saudi Arabia: a bibliometric appraisal", Haq (2017) analyzed 775 papers of the university that were indexed in Web of Science from its inception to 2015. The majority of papers $(15.35 \%)$ were written on the subject of medicine. Most papers (178) were published in 2015. The majority of papers (46\%) were published in the Saudi Medical Journal. Research cooperation with the universities of United States was the highest, with co-authoring 39 papers.

In a study titled as "Publications of Banaras Hindu University during 1989-2016: a threedimensional bibliometric study", Dwivedi (2017) studied 16556 records indexed in the Web of Science. An exponential growth of publications was seen since 2005. Chemistry has maximum publications, followed by physics. Council of Scientific \& Industrial Research was the main collaborator with 443 papers. The main collaborator country was the United States with 607 papers, followed by Germany with 471 papers.

Tsafe, Chiya and Aminu (2016) conducted a bibliometric research under the title "Scholarly publications of librarians in universities in Nigeria: 2000-2012: A bibliometric analysis". One hundred sixty five librarians from 16 universities of the country were taken for the study. Selfdesigned questionnaire was used for data collection. Total number of papers authored by the librarians was 373 , mostly on information technology. The majority of them $(56.9 \%)$ had published at least one paper. Male librarians published more $(81.2 \%)$ than female librarians $(18.8 \%)$.

In a paper titled as "Bibliometric analysis of research publications of Maharshi Dayanand University (Rohtak) during 2000-2013", Siwach and Kumar (2015) studied the research 
contributions (1247 papers) of the university in terms of its publication output during 2000-2013 as reflected through Scopus database. Results showed that the average number of citations per paper was 6 . The trends in published papers and received citations were increasing. The highest number of indexed papers (455 papers) belonged to chemistry. The most highly-productive journal was Indian Journal of Heterocyclic Chemistry with 71 papers.

Sweileh et al. (2014) published a paper titled as "Assessing the scientific research productivity of the Palestinian higher education institutions: A case study at An-Najah National University, Palestine". They analyzed growth, contribution, and impact of research carried out by the faculty members, researchers, or students of the university in the past 35 years. A total of 791 published papers were retrieved for this university in Scopus. Seventeen documents $(2.1 \%)$ were published in Acta Crystallographica Section E Structure Reports Online, as the most productive journal. The majority of papers (146) were in medical field. The study identified 384 (25.8\%) papers with 59 countries as foreign collaborators, with the United States as the first-ranked country with 94 papers.

In "A bibliometric analysis of the research output of Sambalpur University's publication in Web of Science during 2007-2011", Maharana and Sethi (2013) studied 170 papers of the university indexed in the database. Results showed that the majority of papers (47) were in chemistry. Most papers were published in Astrophysics and Space Science Journal. The highest indexed papers belonged to Indian Institute of Technology. The United States ranked first in collaboration with Sambalpur University.

In summarization, it can be said that considering the increasing trend in the scientific publication, evaluating the scientific performance of research institutes is necessary. Universities can use their bibliometric analyses for being informed of their strengths and weaknesses in the scientific production. By using the results of bibliometric analyses, researchers and decision-makers can detect the possible gaps, regulate grants and research resources based on these results and make correct decisions on future programs on the scientific development.

\section{Materials and Methods}

This study used bibliometric techniques and scientific visualization approaches. Scopus was applied for data collection, as the database has been used in many bibliometric studies due to its full coverage of scientific publications and citations (e.g. Sabah et al., 2019; Kamdem et al., 2019; Atayero et al., 2018; Ho et al., 2017; Kazerani et al., 2017; Rondanelli et al., 2016; Batooli et al., 2016; Zyoud et al., 2014; Zyoud et al., 2015; Yessirkepov et al., 2015; Zarei et al. 2015; Sa'ed et al., 2014).

Scopus was established in 2004 by Elsevier, one of the great international publishers in the World. It became one of the main famous citation databases. It provides the bibliographic 
information and abstracts of papers as well as citation-related data of indexed journals and paper rankings based on their received citations (Falagas et al., 2008). By searching Scopus, influential authors, papers, institutions, countries and journals can be identified. It includes many items, including among others, journal articles, conference papers and proceedings, patents, books, editorial notes, letters to editor, reports, reviews and trade documents (Kulkarni et al., 2009).

For retrieving data, the "affiliation search" section in Scopus advanced search section was used for searching for all scientific publications of HUMS until 2018. As the researchers in this university used two forms for their affiliation, the following formula in advanced search section of Scopus was applied:

AF-ID ("Hamedan University of Medical Sciences" 60006672) OR AF-ID ("Hamedan University of Medical Sciences Besat Hospital" 60089189) AND (EXCLUDE (PUBYEAR, 2019))

In total, 3753 papers were retrieved and their bibliographic data extracted. At first, the trends in publications and received citations were studied. Then, the annual citation structures as well as the h-indexes with and without self-citations were analyzed. In addition, the national and international collaborations were studied, followed by determining the more influential and highly-productive authors, highly-cited papers and highly-productive journals. At last, the main subjects of papers were depicted by the clustering technique. Excell and VOSviewer were used for data analysis. VOSviewer aims at facilitating bibliometric analyses and helpful in visualizing and mapping co-authorship, co-citation and co-occurrence patterns (Van Eck, 2009). It presents the scientific maps in various formats by focusing on specific determined aspects. Magnifying, scrolling and searching are some of its features.

\section{Findings}

\section{Scientific publications and received citations}

Figure 1 shows the frequency distribution of papers published by HUMS during 1992-2018. In total, 3753 papers published by the authors affiliated to the university. The first paper was published by H. Pour-Jafari in Veterinary and Human Toxicology and titled as "Alterations of libido in gased Iranian men". The highest number of papers (664) published in 2018. No paper was published in 1993. The lowest number of published papers belonged to 1992, 1995, 1996, 1997, 1999 and 2000, with only one paper in each. Three recent years (2016, 2017 and 2018) had the high numbers in published papers, including 49 percent of all papers. With an increasing trend, the number of papers increased from one paper in 1992 to 664 papers in 2018.

Figure 2 depicts the trend in citations received by the papers published by HUMS during 19922018. As can be seen, received citations showed an increasing trend, too. The number of received citations increased from 4 citations in 1992 to 4713 citations in 2018. As the citing process is time-consuming, the number of received citations in 2018 will certainly increase. 


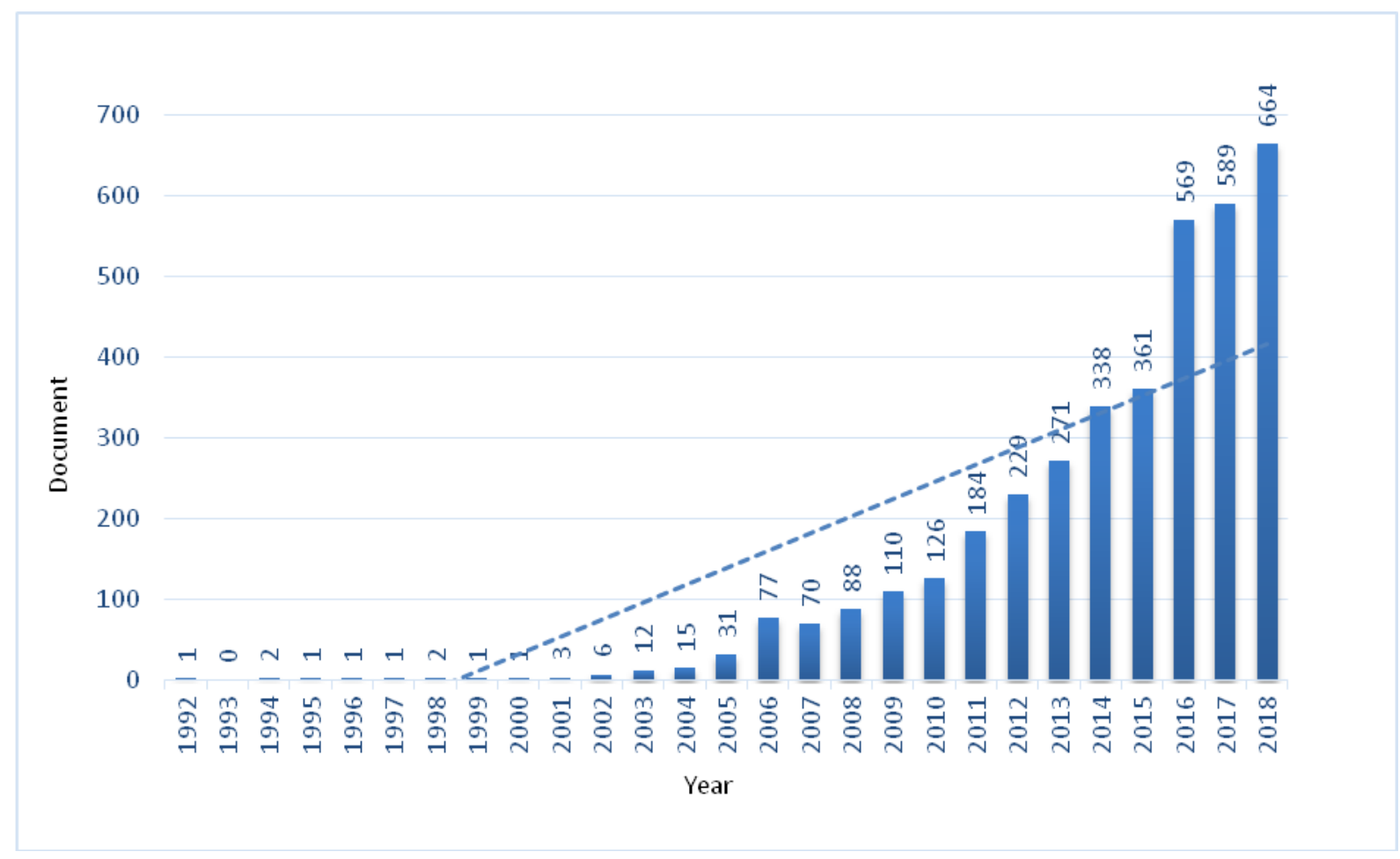

Figure 1. The frequency distribution of papers published by HUMS during 1992-2018

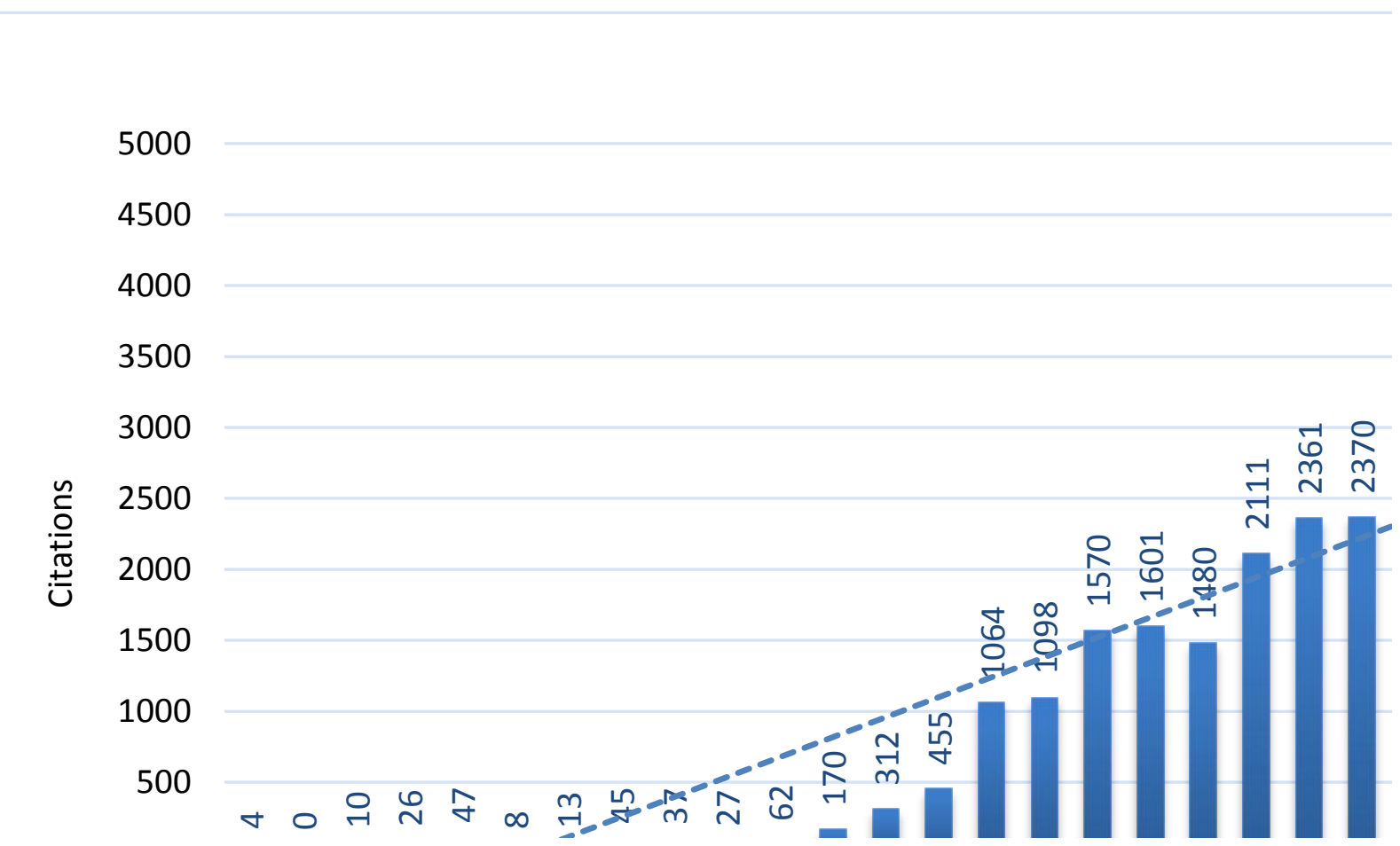

Figure 2. The frequency distribution of citations received by published papers of HUMS during 1992-2018 


\section{The annual citation structure}

Table 1 shows the annual structure of citations received by HUMS's published papers in the studied period. Out of 3753 published papers, 2863 papers (76.29\%) received one or more citations. In other words, only 23.71 percent of papers received no citations. Cited papers received 29650 citations in total (7.90 citations per paper). Fifteen papers (.40\%) received $\geq 100$ citations.

Table 1. Annual citation structure of citations received by HUMS's published papers during 1992-2018

\begin{tabular}{|c|c|c|c|c|c|c|c|c|c|c|c|}
\hline Year & $\geq 100$ & $\geq \mathbf{5 0}$ & $\geq 40$ & $\geq \mathbf{3 0}$ & $\geq 20$ & $\geq 10$ & $\geq 1$ & O & TP & TC & CPP \\
\hline 2018 & 3 & 2 & 1 & 1 & 5 & 15 & 315 & 322 & 664 & 1656 & 2.49 \\
\hline 2017 & 5 & 1 & 1 & 2 & 5 & 47 & 351 & 177 & 589 & 4713 & 8.00 \\
\hline 2016 & 1 & 2 & 2 & 8 & 12 & 78 & 337 & 129 & 569 & 3154 & 5.54 \\
\hline 2015 & 0 & 1 & 4 & 11 & 26 & 53 & 212 & 54 & 361 & 2777 & 7.69 \\
\hline 2014 & 0 & 0 & 1 & 6 & 22 & 68 & 186 & 55 & 338 & 2478 & 7.33 \\
\hline 2013 & 0 & 5 & 5 & 12 & 11 & 43 & 155 & 40 & 271 & 2370 & 8.75 \\
\hline 2012 & 2 & 3 & 6 & 3 & 19 & 44 & 117 & 35 & 229 & 2361 & 10.31 \\
\hline 2011 & 1 & 3 & 3 & 8 & 15 & 50 & 81 & 23 & 184 & 2111 & 11.47 \\
\hline 2010 & 1 & 3 & 2 & 8 & 8 & 20 & 69 & 15 & 126 & 1480 & 11.75 \\
\hline 2009 & 1 & 4 & 3 & 3 & 8 & 31 & 49 & 11 & 110 & 1601 & 14.55 \\
\hline 2008 & 1 & 3 & 7 & 4 & 14 & 15 & 33 & 11 & 88 & 1570 & 17.84 \\
\hline 2007 & 0 & 3 & 3 & 6 & 8 & 18 & 29 & 3 & 70 & 1098 & 15.69 \\
\hline 2006 & 0 & 4 & 4 & 2 & 7 & 21 & 31 & 8 & 77 & 1064 & 13.82 \\
\hline 2005 & 0 & 3 & 2 & 0 & 1 & 6 & 13 & 6 & 31 & 455 & 14.68 \\
\hline 2004 & 0 & 1 & 1 & 3 & 3 & 1 & 5 & 1 & 15 & 313 & 20.87 \\
\hline 2003 & 0 & 1 & 0 & 1 & 0 & 2 & 8 & 0 & 12 & 170 & 14.17 \\
\hline 2002 & 0 & 0 & 0 & 1 & 0 & 1 & 4 & 0 & 6 & 62 & 10.33 \\
\hline 2001 & 0 & 0 & 0 & 0 & 1 & 0 & 2 & 0 & 3 & 27 & 9.00 \\
\hline 2000 & 0 & 0 & 0 & 1 & 0 & 0 & 0 & 0 & 1 & 37 & 37.00 \\
\hline 1999 & 0 & 0 & 1 & 0 & 0 & 0 & 0 & 0 & 1 & 45 & 45.00 \\
\hline 1998 & 0 & 0 & 0 & 0 & 0 & 1 & 1 & 0 & 2 & 13 & 6.50 \\
\hline 1997 & 0 & 0 & 0 & 0 & 0 & 0 & 1 & 0 & 1 & 8 & 8.00 \\
\hline 1996 & 0 & 0 & 1 & 0 & 0 & 0 & 0 & 0 & 1 & 47 & 47.00 \\
\hline 1995 & 0 & 0 & 0 & 0 & 1 & 0 & 0 & 0 & 1 & 26 & 26.00 \\
\hline 1994 & 0 & 0 & 0 & 0 & 0 & 0 & 2 & 0 & 2 & 10 & 5.00 \\
\hline 1993 & 0 & 0 & 0 & 0 & 0 & 0 & 0 & 0 & 0 & 0 & 0 \\
\hline 1992 & 0 & 0 & 0 & 0 & 0 & 0 & 1 & 0 & 1 & 4 & 4.00 \\
\hline Total & 15 & 39 & 47 & 80 & 166 & 514 & 2002 & 890 & 3753 & \multirow{2}{*}{29650} & \multirow{2}{*}{7.90} \\
\hline$\%$ & 0.40 & 1.04 & 1.25 & 2.13 & 4.42 & 13.70 & 53.34 & 23.71 & 100.00 & & \\
\hline \multicolumn{12}{|c|}{ TP: Total Papers; TC: Total Citations; CPP: Citations per Paper } \\
\hline
\end{tabular}




\section{H-indexes of papers with and without self-citations}

Table 2 shows the h-indexes of published papers of HUMS during 1992-2018 before and after removing self-citations. Of 29650 received citations, 6934 (23.38\%) were self-citations, i.e. citations received by the authors affiliated to HUMS. The highest h-index before excluding selfcitations was 25 and belonged to 2015. The lowest h-index before excluding self-citations was 1 and belonged to years 1992, 1995, 1996, 1997, 1999 and 2000. As no papers were published in 1993, the h-index in this year was 0 .

For detecting the effect of self-citations on annual h-indexes, it is needed that the h-indexes are compared with and without self-citations. As table 2 shows, after excluding self-citations, the highest h-index decreased from 25 to 20 . This not the case in the lowest h-index amounted to 1. The highest h-index after excluding self-citations was 21 and belonged to the years 2012 and 2013 and the lowest h-index was 1 and belonged to the years 1992, 1995, 1996, 1997, 1999 and 2000 .

Table 2. The frequency distribution of papers, citations, self-citations and h-indexes of papers published by HUMS during 1992-2018

\begin{tabular}{ccccccc}
\hline Year & $\begin{array}{c}\text { Total } \\
\text { papers }\end{array}$ & $\begin{array}{c}\text { Total } \\
\text { citations }\end{array}$ & $\begin{array}{c}\text { H-index } \\
\text { with self- } \\
\text { citations }\end{array}$ & $\begin{array}{c}\text { Self- } \\
\text { citations }\end{array}$ & $\begin{array}{c}\text { Citations } \\
\text { without self- } \\
\text { citations }\end{array}$ & $\begin{array}{c}\text { H-index } \\
\text { without self- } \\
\text { citations }\end{array}$ \\
\hline 1992 & 1 & 4 & 1 & 0 & 4 & 1 \\
1993 & 0 & 0 & 0 & 0 & 0 & 0 \\
1994 & 2 & 10 & 2 & 0 & 10 & 2 \\
1995 & 1 & 26 & 1 & 13 & 13 & 1 \\
1996 & 1 & 47 & 1 & 1 & 46 & 1 \\
1997 & 1 & 8 & 1 & 0 & 8 & 1 \\
1998 & 2 & 13 & 2 & 1 & 12 & 2 \\
1999 & 1 & 45 & 1 & 6 & 39 & 1 \\
2000 & 1 & 37 & 1 & 20 & 17 & 1 \\
2001 & 3 & 27 & 2 & 8 & 19 & 2 \\
2002 & 6 & 62 & 4 & 10 & 52 & 6 \\
2003 & 12 & 170 & 7 & 14 & 156 & 8 \\
2004 & 15 & 313 & 9 & 56 & 257 & 10 \\
2005 & 31 & 455 & 11 & 88 & 367 & 18 \\
2006 & 77 & 1064 & 19 & 182 & 882 & 18 \\
2007 & 70 & 1098 & 20 & 180 & 918 & 20 \\
2008 & 88 & 1570 & 22 & 267 & 1303 & 18 \\
2009 & 110 & 1601 & 19 & 269 & 1332 & 19 \\
2010 & 126 & 1480 & 21 & 204 & 1276 & 19 \\
2011 & 184 & 2111 & 23 & 462 & 1649 & 6 \\
\hline
\end{tabular}




\begin{tabular}{lcccccc}
\hline 2012 & 229 & 2361 & 23 & 461 & 1900 & 21 \\
2013 & 271 & 2370 & 24 & 539 & 1831 & 21 \\
2014 & 338 & 2478 & 22 & 590 & 1888 & 18 \\
2015 & 362 & 2777 & 25 & 845 & 1932 & 20 \\
2016 & 568 & 3154 & 21 & 922 & 2232 & 18 \\
2017 & 589 & 4713 & 17 & 1235 & 3478 & 13 \\
2018 & 664 & 1656 & 15 & 561 & 1095 & 12 \\
Total & 3753 & 29650 & 53 & 6934 & 22716 & 47 \\
\hline
\end{tabular}

\section{National and International Collaborations}

The frequency distribution of national collaborations made by HUMS's researchers is shown in Table 3. The first rank belonged to Tehran University of Medical Sciences collaborating in authoring 740 papers, followed by Shahid Beheshti University of Medical Sciences with 503 papers and Iran University of Medical Sciences with 291 papers. About 41 percent of HUMS's national collaboration was with these three universities.

Table 3. Top 20 national institutions collaborating with HUMS during 1992-2018

\begin{tabular}{llll}
\hline Rank & \multicolumn{1}{c}{ Afflation } & Total papers & \% \\
\hline 1 & Tehran University of Medical Sciences & 740 & 19.72 \\
2 & Shahid Beheshti University of Medical Sciences & 503 & 13.40 \\
3 & Iran University of Medical Sciences & 291 & 7.75 \\
4 & Kermanshah University of Medical Sciences & 240 & 6.39 \\
5 & Kurdistan University of Medical Sciences & 173 & 4.61 \\
6 & Bu-Ali Sina University & 141 & 3.76 \\
7 & Isfahan University of Medical Sciences & 139 & 3.70 \\
8 & Tabriz University of Medical Sciences & 131 & 3.49 \\
9 & Shiraz University of Medical Sciences & 98 & 2.61 \\
9 & Zahedan University of Medical Sciences & 98 & 2.61 \\
10 & Ahvaz Jundishapur University of Medical Sciences & 92 & 2.45 \\
11 & Ilam University of Medical Sciences & 87 & 2.32 \\
12 & Tarbiat Modares University & 85 & 2.26 \\
12 & Qom University of Medical Sciences & 85 & 2.26 \\
13 & Baqiyatallah University of Medical Sciences & 84 & 2.24 \\
14 & Islamic Azad University & 83 & 2.21 \\
15 & Mashhad University of Medical Sciences & 78 & 2.08 \\
16 & University of Tehran & 71 & 1.89 \\
17 & Pasteur Institute of Iran & 66 & 1.75 \\
18 & Mazandaran University of Medical Sciences & 65 & 1.73 \\
19 & Guilan University of Medical Sciences & 64 & 1.71 \\
20 & Islamic Azad University, Hamedan Branch & 64 & 1.71 \\
20 & Rafsanjan University of Medical Sciences & 62 & 1.65 \\
\hline
\end{tabular}


The frequency distribution of international collaborations made by HUMS's researchers is shown in Table 4. It collaborated with 121 countries worldwide. The United States ranked first by authoring 107 papers $(2.85 \%)$ in collaboration with HUMS, followed by the United Kingdom $(1.64 \%)$ and Switzerland (1.57\%). The lowest collaboration belonged to Barbados, Cyprus, Equatorial Guinea, Gambia, Hungary, Jamaica, Malawi, Mauritania, and Sudan, each with one paper $(.02 \%)$.

Table 4. Countries collaborating with HUMS during 1992-2018 and the share of their contribution

\begin{tabular}{|c|c|c|c|c|c|c|c|c|}
\hline Country & $\begin{array}{c}\text { Total } \\
\text { papers }\end{array}$ & $\%$ & Country & $\begin{array}{c}\text { Total } \\
\text { papers }\end{array}$ & $\%$ & Country & $\begin{array}{c}\text { Total } \\
\text { papers }\end{array}$ & $\%$ \\
\hline $\begin{array}{l}\text { United } \\
\text { States }\end{array}$ & 107 & 2.85 & Bangladesh & 15 & 0.39 & Palestine & 11 & 0.29 \\
\hline $\begin{array}{l}\text { United } \\
\text { Kingdom }\end{array}$ & 69 & 1.84 & Colombia & 15 & 0.39 & Zambia & 11 & 0.29 \\
\hline Switzerland & 59 & 1.57 & Estonia & 15 & 0.39 & Argentina & 10 & 0.26 \\
\hline Australia & 58 & 1.55 & Ghana & 15 & 0.39 & Kazakhstan & 10 & 0.26 \\
\hline Malaysia & 55 & 1.47 & Indonesia & 15 & 0.39 & Kuwait & 10 & 0.26 \\
\hline Canada & 50 & 1.33 & Lebanon & 15 & 0.39 & Tunisia & 10 & 0.26 \\
\hline Italy & 38 & 1.01 & Mexico & 15 & 0.39 & Liberia & 9 & 0.23 \\
\hline Japan & 37 & 0.99 & Nepal & 15 & 0.39 & $\begin{array}{c}\text { Burundi } \\
\text { Darussalam }\end{array}$ & 8 & 0.21 \\
\hline Germany & 36 & 0.96 & Peru & 15 & 0.39 & Namibia & 8 & 0.21 \\
\hline Sweden & 36 & 0.96 & Romania & 15 & 0.39 & Bhutan & 7 & 0.18 \\
\hline Finland & 28 & 0.75 & $\begin{array}{c}\text { United Arab } \\
\text { Emirates }\end{array}$ & 15 & 0.39 & Slovenia & 7 & 0.18 \\
\hline India & 28 & 0.75 & Viet Nam & 15 & 0.39 & Yemen & 7 & 0.18 \\
\hline France & 26 & 0.69 & Austria & 14 & 0.37 & Armenia & 6 & 0.15 \\
\hline $\begin{array}{l}\text { South } \\
\text { Korea }\end{array}$ & 26 & 0.69 & Bahrain & 14 & 0.37 & Morocco & 6 & 0.15 \\
\hline Netherlands & 24 & 0.63 & Benin & 14 & 0.37 & Thailand & 6 & 0.15 \\
\hline Turkey & 24 & 0.63 & Cameroon & 14 & 0.37 & Uganda & 6 & 0.15 \\
\hline Brazil & 23 & 0.61 & Chile & 14 & 0.37 & Georgia & 5 & 0.13 \\
\hline Norway & 23 & 0.61 & Kyrgyzstan & 14 & 0.37 & Oman & 5 & 0.13 \\
\hline $\begin{array}{l}\text { South } \\
\text { Africa }\end{array}$ & 23 & 0.61 & Luxembourg & 14 & 0.37 & $\begin{array}{c}\text { New } \\
\text { Caledonia }\end{array}$ & 4 & 0.10 \\
\hline China & 22 & 0.58 & Panama & 14 & 0.37 & $\begin{array}{c}\text { Trinidad and } \\
\text { Tobago }\end{array}$ & 4 & 0.10 \\
\hline Pakistan & 22 & 0.58 & Philippines & 14 & 0.37 & Botswana & 3 & 0.07 \\
\hline Belgium & 21 & 0.55 & Afghanistan & 13 & 0.34 & $\begin{array}{c}\text { Libyan Arab } \\
\text { Jamahiriya }\end{array}$ & 3 & 0.07 \\
\hline Hong Kong & 20 & 0.53 & Anguilla & 13 & 0.34 & Malta & 3 & 0.07 \\
\hline Denmark & 19 & 0.50 & $\begin{array}{l}\text { Congo } \\
\text { Federated }\end{array}$ & 13 & 0.34 & Myanmar & 3 & 0.07 \\
\hline Spain & 19 & 0.50 & $\begin{array}{c}\text { States of } \\
\text { Micronesia }\end{array}$ & 13 & 0.34 & Togo & 3 & 0.07 \\
\hline Iraq & 18 & 0.47 & Ireland & 13 & 0.34 & Burundi & 2 & 0.05 \\
\hline Poland & 18 & 0.47 & Israel & 13 & 0.34 & Chad & 2 & 0.05 \\
\hline
\end{tabular}




\begin{tabular}{|c|c|c|c|c|c|c|c|c|}
\hline $\begin{array}{l}\text { Saudi } \\
\text { Arabia }\end{array}$ & 18 & 0.47 & Mozambique & 13 & 0.34 & Cote d'Ivoire & 2 & 0.05 \\
\hline Ethiopia & 17 & 0.45 & Qatar & 13 & 0.34 & $\begin{array}{c}\text { Papua New } \\
\text { Guinea }\end{array}$ & 2 & 0.05 \\
\hline $\begin{array}{c}\text { New } \\
\text { Zealand }\end{array}$ & 17 & 0.45 & Slovakia & 13 & 0.34 & $\begin{array}{l}\text { Syrian Arab } \\
\text { Republic }\end{array}$ & 2 & 0.05 \\
\hline Nigeria & 17 & 0.45 & Sri Lanka & 13 & 0.34 & Uruguay & 2 & 0.05 \\
\hline Egypt & 16 & 0.42 & Ukraine & 13 & 0.34 & Barbados & 1 & 0.02 \\
\hline Jordan & 16 & 0.42 & Bulgaria & 12 & 0.31 & Cyprus & 1 & 0.02 \\
\hline Kenya & 16 & 0.42 & Costa Rica & 12 & 0.31 & $\begin{array}{c}\text { Equatorial } \\
\text { Guinea }\end{array}$ & 1 & 0.02 \\
\hline Portugal & 16 & 0.42 & Ecuador & 12 & 0.31 & Gambia & 1 & 0.02 \\
\hline $\begin{array}{l}\text { Russian } \\
\text { Federation }\end{array}$ & 16 & 0.42 & Iceland & 12 & 0.31 & Hungary & 1 & 0.02 \\
\hline Serbia & 16 & 0.42 & Rwanda & 12 & 0.31 & Jamaica & 1 & 0.02 \\
\hline Singapore & 16 & 0.42 & Tanzania & 12 & 0.31 & Malawi & 1 & 0.02 \\
\hline Taiwan & 16 & 0.42 & Croatia & 11 & 0.29 & Mauritania & 1 & 0.02 \\
\hline Algeria & 15 & 0.39 & Greece & 11 & 0.29 & Sudan & 1 & 0.02 \\
\hline
\end{tabular}

Figure 3 depicts the co-authorship map of countries with at least 20 papers coauthored by HUMS's researchers. These countries include: United States, United Kingdom, Switzerland, Australia, Malaysia, Canada, Italy, Japan, Germany, Sweden, Finland, India, France, South Korea, Netherlands, Turkey, Brazil, Norway, South Africa, China, Pakistan, Belgium and Hong Kong. In the co-authorship map, the size of circles demonstrates the magnitude of the publication number and line thickness does that of the co-authorship rate. As can be seen, the high rates of co-authorship belonged to the United States (107 papers), the United Kingdom (69 papers), Switzerland (59 papers), Australia (58 papers) and Malaysia (55 papers).

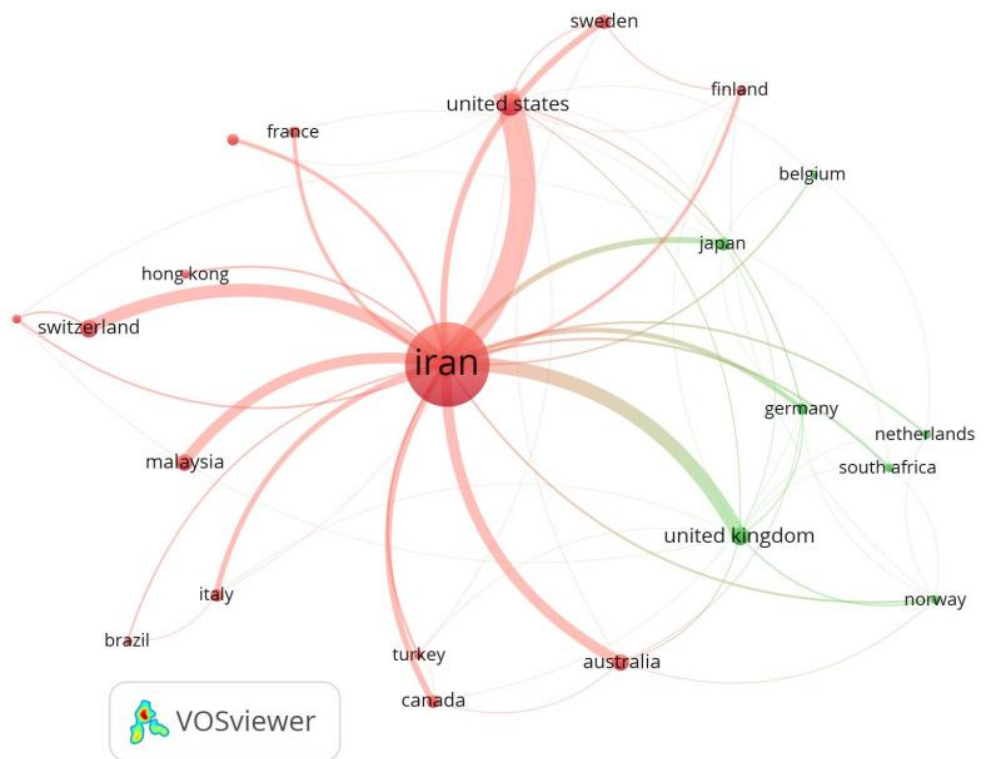

Figure 3. The co-authorship map of countries collaborating with HUMS during 1992-2018 


\section{Highly productive and more influential authors}

The top 20 highly productive authors in HUMS are shown in table 5 according to the number of their published papers. The table includes author names, departments, and the number of coauthors, papers and citations, as well as h-indexes. The most highly-productive author was $\mathrm{S}$. Khazaei with 141 papers and 356 received citations and h-index of 9. J. Poorolajal with 140 papers and M. Saidijam with 107 papers ranked second and third, respectively.

Table 5. Top 20 authors of HUMS in terms of number of their papers

\begin{tabular}{|c|c|c|c|c|c|c|}
\hline Rank & Authors & Department & $\begin{array}{c}\text { Total } \\
\text { papers }\end{array}$ & $\begin{array}{c}\text { Total } \\
\text { citations }\end{array}$ & $\begin{array}{c}\text { H- } \\
\text { index }\end{array}$ & $\begin{array}{c}\text { Co- } \\
\text { authors }\end{array}$ \\
\hline 1 & Khazaei, S. & Health Sciences Research Center & 141 & 356 & 9 & 158 \\
\hline 2 & Poorolajal, J. & School of Health & 140 & 1412 & 19 & 348 \\
\hline 3 & Saidijam, M. & School of Medicine & 107 & 1258 & 18 & 346 \\
\hline 4 & Alikhani, M.Y. & School of Medicine & 99 & 855 & 15 & 279 \\
\hline 5 & Karami, M. & School of Health & 98 & 772 & 12 & 2136 \\
\hline 6 & Komaki, A. & School of Medicine & 89 & 918 & 19 & 171 \\
\hline 7 & Goodarzi, M.T. & School of Medicine & 88 & 1075 & 18 & 232 \\
\hline 8 & Shahidi, S. & School of Medicine & 81 & 1019 & 20 & 127 \\
\hline 9 & Moghimbeigi, A. & School of Health & 78 & 576 & 13 & 211 \\
\hline 10 & Ayubi, E. & School of Medicine & 72 & 576 & 11 & 146 \\
\hline 10 & Mahjub, $\mathrm{H}$. & School of Health & 72 & 597 & 14 & 153 \\
\hline 11 & Roshanaei, G. & School of Health & 71 & 283 & 10 & 208 \\
\hline 11 & Tavilani, $\mathrm{H}$. & School of Medicine & 71 & 1029 & 19 & 158 \\
\hline 12 & Mansori, K. & School of Medicine & 68 & 190 & 7 & 137 \\
\hline 13 & Hajilooi, M. & School of Medicine & 65 & 642 & 14 & 203 \\
\hline 14 & Asgari, G. & School of Health & 61 & 709 & 15 & 125 \\
\hline 15 & Khodadadi, I. & School of Medicine & 60 & 413 & 11 & 133 \\
\hline 16 & Bahrami, A. & School of Health & 56 & 523 & 13 & 93 \\
\hline 16 & Shobeiri, F. & School of Nursing and Midwifery & 56 & 404 & 13 & 75 \\
\hline 16 & Soltanian, A.R. & School of Health & 56 & 551 & 14 & 270 \\
\hline 17 & Salehi, I & School of Allied Medical Sciences & 55 & 617 & 16 & 153 \\
\hline 18 & Sarihi, A. & School of Medicine & 54 & 641 & 16 & 101 \\
\hline 19 & Ghaleiha, A. & School of Medicine & 53 & 659 & 15 & 184 \\
\hline 20 & Farhadian, M. & School of Health & 52 & 116 & 5 & 154 \\
\hline
\end{tabular}


The co-authorship map of highly-productive authors of HUMS was depicted in figure 4 . The top 50 authors were included in the map. The map includes several clusters. Authors with more coauthorship with each other were included in the same cluster. The size of circles shows the magnitude of the paper number and the thickness of lines shows that of the co-authorship rate. The co-authorship map of HUMS consists of 6 clusters. The first cluster (in red) has 20 authors, with J. Poorolajal as the core author with 140 papers. The second cluster (in green) includes 8 authors with M. Saidijam as the core author with 107 published papers. The third cluster (in blue) has 7 authors in which A. Ghaleiha is the core author with 53 papers. The fourth cluster (in yellow) has 6 authors. The fifth cluster (in violet) has 5 authors and the sixth one (in bright blue) has 4 authors.

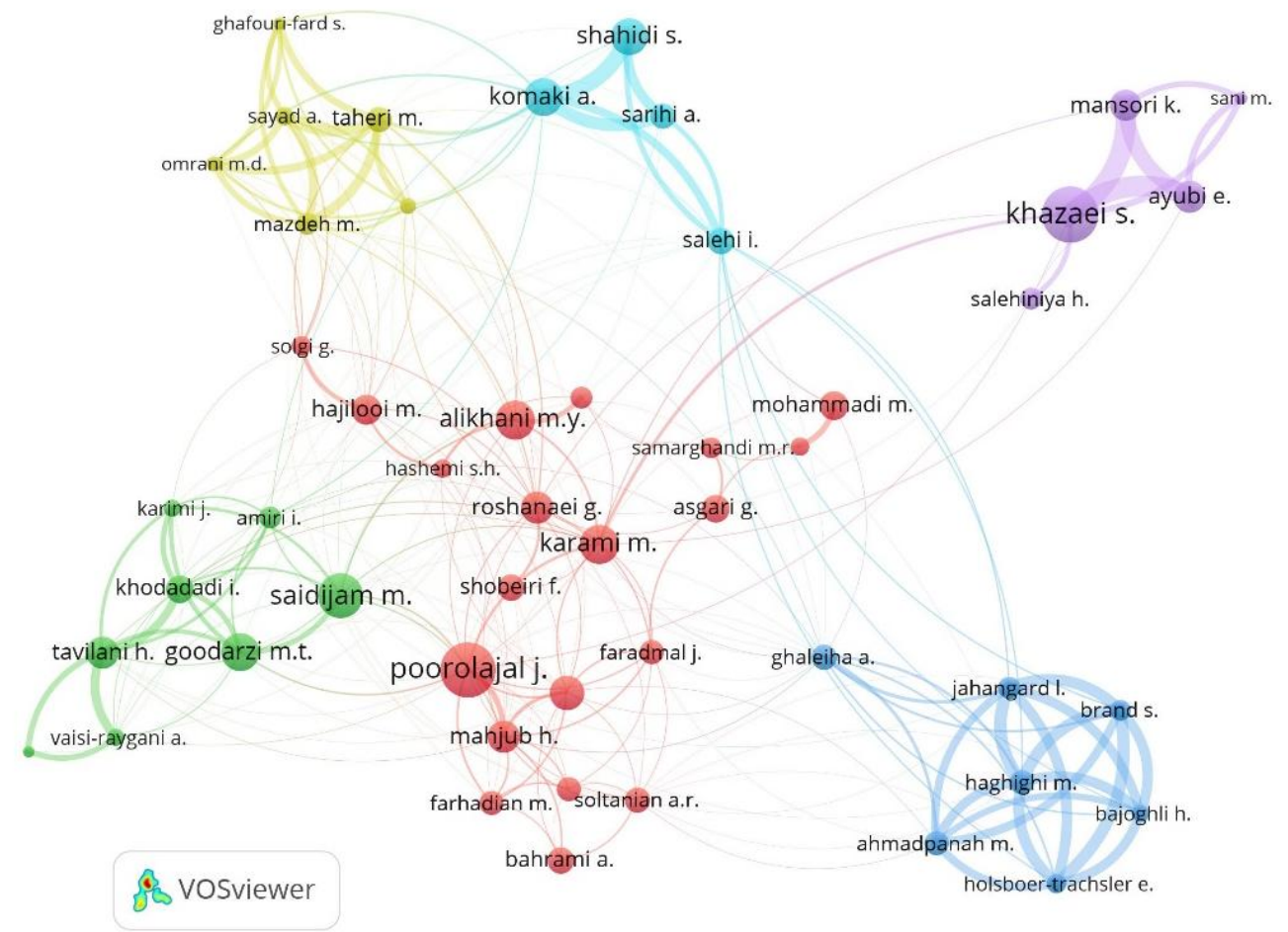

Figure 4. The co-authorship map of highly-productive authors of HUMS during 1992-2018

\section{Top publishing journals}

Table 6 shows the top ten journals publishing the papers authored by HUMS's researchers during 1992-2018. Most papers of the university were published in the Journal of Research in Health Sciences, followed by Iranian Journal of Public Health and Journal of Mazandaran University of Medical Sciences. Of these journals, 5, 2 and 3 journals are in Quartiles 2, 3 and 4, respectively. Of them, 8 journals are from Iran. 
Table 6. Top ten journals publishing papers of HUMS during 1992-2018

\begin{tabular}{|c|c|c|c|c|c|}
\hline Rank & Journal Title & $\begin{array}{c}\text { Total } \\
\text { papers }\end{array}$ & $\begin{array}{l}\text { Publishing } \\
\text { country }\end{array}$ & $\begin{array}{c}\text { Cite } \\
\text { Score } \\
(2018) \\
\end{array}$ & $\begin{array}{c}\text { Cite Score } \\
\text { Quartile } \\
(2018) \\
\end{array}$ \\
\hline 1 & $\begin{array}{c}\text { Journal of Research in Health } \\
\text { Sciences }\end{array}$ & 114 & Iran & 1.34 & Q2 \\
\hline 2 & Iranian Journal of Public Health & 77 & Iran & 0.93 & Q3 \\
\hline 3 & $\begin{array}{c}\text { Journal of Mazandaran University } \\
\text { of Medical Sciences }\end{array}$ & 67 & Iran & 0.47 & Q3 \\
\hline 4 & Iran Occupational Health & 55 & Iran & 0.32 & Q4 \\
\hline 5 & $\begin{array}{c}\text { Asian Pacific Journal of Cancer } \\
\text { Prevention }\end{array}$ & 50 & Iran & 1.47 & Q2 \\
\hline 6 & Desalination and Water Treatment & 43 & USA & 1.36 & Q2 \\
\hline 7 & Acta Medica Iranica & 41 & Iran & 0.91 & Q2 \\
\hline 8 & $\begin{array}{l}\text { Journal of Clinical and } \\
\text { Diagnostic Research }\end{array}$ & 37 & India & 0.82 & Q3 \\
\hline 9 & $\begin{array}{c}\text { Iranian Red Crescent Medical } \\
\text { Journal }\end{array}$ & 36 & Iran & 1.16 & Q2 \\
\hline 10 & International Journal of Pediatrics & 31 & Iran & 0.08 & Q4 \\
\hline
\end{tabular}

\section{Highly-cited papers}

Table 7 shows some features of top ten highly-cited papers authored by HUMS's researchers. Entitled as "Health effects of overweight and obesity in 195 countries over 25 years", the most highly-cited paper was published in 2017 in the New England Journal of Medicine, with M. Shamsizadeh as a coauthor from HUMS. It is interesting that all highly-cited papers were published in Q1 journals.

Table 7. Top ten highly-cited papers authored/co-authored by HUMS during 1992-2018

\begin{tabular}{|c|c|c|c|c|c|c|c|}
\hline Rank & Paper title & $\begin{array}{l}\text { Author from } \\
\text { HUMS }\end{array}$ & Journal Title & $\begin{array}{l}\text { Impact } \\
\text { Factor }\end{array}$ & $\begin{array}{l}\text { Cite } \\
\text { Score }\end{array}$ & $\begin{array}{l}\text { Pub. } \\
\text { Year }\end{array}$ & $\begin{array}{l}\text { Cit } \\
\text { ed } \\
\text { by }\end{array}$ \\
\hline 1 & $\begin{array}{l}\text { Health effects of overweight and } \\
\text { obesity in } 195 \text { countries over } 25 \text { years }\end{array}$ & $\begin{array}{c}\text { M. } \\
\text { Shamsizadeh }\end{array}$ & $\begin{array}{c}\text { New England } \\
\text { Journal of } \\
\text { Medicine }\end{array}$ & $\begin{array}{c}70.76 \\
\text { Q1 }\end{array}$ & $\begin{array}{c}16.1 \\
\text { Q1 }\end{array}$ & 2017 & 794 \\
\hline 2 & $\begin{array}{l}\text { Global, regional, and national age-sex } \\
\text { specific mortality for } 264 \text { causes of } \\
\text { death, 1980-2016: A systematic } \\
\text { analysis for the Global Burden of } \\
\text { Disease Study } 2016\end{array}$ & $\begin{array}{c}\text { M. } \\
\text { Shamsizadeh }\end{array}$ & The Lancet & $\begin{array}{c}59.102 \\
\text { Q1 }\end{array}$ & $\begin{array}{c}10.28 \\
\text { Q1 }\end{array}$ & 2017 & 787 \\
\hline 3 & $\begin{array}{l}\text { Global, regional, and national } \\
\text { comparative risk assessment of } 84 \\
\text { behavioural, environmental and } \\
\text { occupational, and metabolic risks or }\end{array}$ & $\begin{array}{c}\text { M. } \\
\text { Shamsizadeh }\end{array}$ & The Lancet & $\begin{array}{c}59.102 \\
\text { Q1 }\end{array}$ & $\begin{array}{c}10.28 \\
\text { Q1 }\end{array}$ & 2017 & 547 \\
\hline
\end{tabular}




\begin{tabular}{|c|c|c|c|c|c|c|c|}
\hline & $\begin{array}{l}\text { clusters of risks, 1990-2016: A } \\
\text { systematic analysis for the Global } \\
\text { Burden of Disease Study } 2016\end{array}$ & & & & & & \\
\hline 4 & $\begin{array}{l}\text { Global, regional, and national burden } \\
\text { of neurological disorders during } \\
\text { 1990-2015: a systematic analysis for } \\
\text { the Global Burden of Disease Study } \\
2015\end{array}$ & $\begin{array}{c}\text { M. } \\
\text { Shamsizadeh }\end{array}$ & $\begin{array}{l}\text { The Lancet } \\
\text { Neurology }\end{array}$ & $\begin{array}{c}28.755 \\
\mathrm{Q} 1\end{array}$ & $\begin{array}{c}8.81 \\
\mathrm{Q} 1\end{array}$ & 2017 & 276 \\
\hline 5 & $\begin{array}{l}\text { Structure and molecular mechanism } \\
\text { of a nucleobase-cation-symport-1 } \\
\text { family transporter }\end{array}$ & $\begin{array}{c}\text { M. } \\
\text { Saidijam }\end{array}$ & Science & $\begin{array}{l}41.037 \\
\mathrm{Q} 1\end{array}$ & $\begin{array}{c}15.21 \\
\mathrm{Q} 1\end{array}$ & 2008 & 259 \\
\hline 6 & $\begin{array}{l}\text { The properties and applications of } \\
\text { chlorhexidine in endodontics }\end{array}$ & $\begin{array}{c}\text { Z. } \\
\text { Mohammadi }\end{array}$ & $\begin{array}{l}\text { International } \\
\text { Endodontic } \\
\text { Journal }\end{array}$ & $\begin{array}{c}3.331 \\
\mathrm{Q} 1\end{array}$ & $\begin{array}{c}3.57 \\
\mathrm{Q} 1\end{array}$ & 2009 & 214 \\
\hline 7 & $\begin{array}{l}\text { Global, regional, and national under- } \\
5 \text { mortality, adult mortality, age- } \\
\text { specific mortality, and life } \\
\text { expectancy, 1970-2016: A systematic } \\
\text { analysis for the Global Burden of } \\
\text { Disease Study } 2016\end{array}$ & $\begin{array}{c}\text { M. } \\
\text { Shamsizadeh }\end{array}$ & The Lancet & $\begin{array}{l}59.102 \\
\mathrm{Q} 1\end{array}$ & $\begin{array}{c}10.28 \\
\mathrm{Q} 1\end{array}$ & 2017 & 200 \\
\hline 8 & $\begin{array}{l}\text { Properties and applications of } \\
\text { calcium hydroxide in endodontics } \\
\text { and dental traumatology }\end{array}$ & $\begin{array}{c}\text { Z. } \\
\text { Mohammadi }\end{array}$ & $\begin{array}{l}\text { International } \\
\text { Endodontic } \\
\text { Journal }\end{array}$ & $\begin{array}{l}3.331 \\
\mathrm{Q} 1\end{array}$ & $\begin{array}{l}3.57 \\
\mathrm{Q} 1\end{array}$ & 2011 & 198 \\
\hline 9 & $\begin{array}{l}\text { Equilibrium two-parameter isotherms } \\
\text { of acid dyes sorption by activated } \\
\text { carbons: Study of residual errors }\end{array}$ & Mahdi Hadi & $\begin{array}{l}\text { Chemical } \\
\text { Engineering } \\
\text { Journal }\end{array}$ & $\begin{array}{l}8.355 \\
\mathrm{Q} 1\end{array}$ & $\begin{array}{l}8.47 \\
\mathrm{Q} 1\end{array}$ & 2010 & 162 \\
\hline 10 & $\begin{array}{l}\text { Effect of Body Mass Index on Breast } \\
\text { Cancer during Premenopausal and } \\
\text { Postmenopausal Periods: A Meta- } \\
\text { Analysis }\end{array}$ & J. Poorolajal & PLoS ONE & $\begin{array}{l}2.766 \\
\text { Q1 }\end{array}$ & $\begin{array}{l}3.01 \\
\mathrm{Q} 1\end{array}$ & 2012 & 141 \\
\hline
\end{tabular}

\section{Clustering papers}

63,362 terms were used in the titles and abstracts of the papers published by HUMS's researchers. As a threshold, the terms with at least 50 frequencies were included in the clustering map. As figure 5 depicts, 4 clusters appeared. The first cluster (in red) includes the terms such as Iran, age, man, life, age group and death. This cluster can be named as "epidemiological studies". The second cluster (in green) consists of terms such as rat, cell, animal, and mechanism. This cluster can be entitled as "laboratory studies". The third cluster (in blue) was named "pharmacologic studies" with terms such as concentration, effect, efficiency, and removal. In the fourth cluster (in yellow), there are terms such as gene, strain, polymorphism, bacterium, and infection. The cluster can be labeled as "microbiologic studies". 


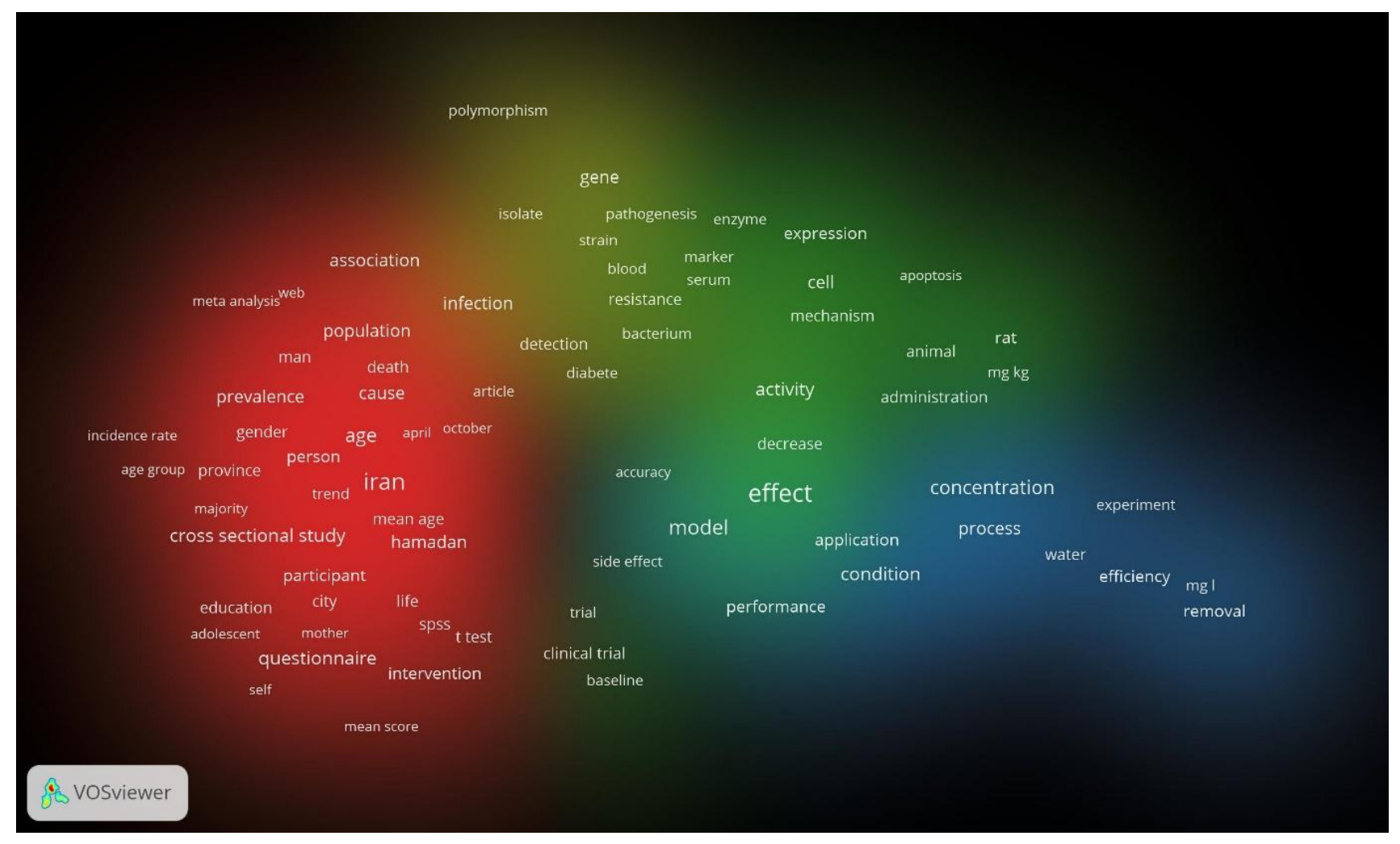

Figure 5. Term clustering of papers authored/co-authored by HUMS during 1992-2018

\section{Discussion and Conclusion}

As influential institutions in society, universities have the protective role in scientific, technological, economic, social and cultural development by producing scientific knowledge in different fields. Therefore, they need to be evaluated from different perspectives. This study is one of the first studies regarding the total scientific production of a medical university in Iran as a developing country and aimed to study the publications of HUMS from a bibliometric aspect. It was found that the growth trend in publications was increasingly, especially in three recent years (2016-2018). This clearly indicates that the university has found its way in research production and considered the importance of externalizing research findings. This is in line with a study by Ahmed et al. (2019) where they found that the two-third publications of Al-Jouf University, Saudi Arabia were produced during 2013-2017. Siwach and Kumar (2015) and Dwivedi (2017) found such a trend in Maharshi Dayanand University and Banaras Hindu University.

HUMS's received citations had an increasing trend with having at least one citation in about 77 percent of its published papers. This is a sign of the university's influence on scientific development. This finding accords with the study by Siwach and Kumar (2015) in case of Maharshi Dayanand University. However, the average citations per paper indicator was 7.90 in HUMS in comparison with those of Maharshi Dayanand University with 6 (Siwach \& Kumar, 
2015) and Al-Jouf University with 4.53 (Ahmed et al., 2019). This difference may be due to the type of studied universities as medical vs. non-medical universities. As the self-citation rate of HUMS was about 23 percent, it is better that the researchers of the university consider citing other universities and research institution in order to reduce the self-citation rate.

Considering the collaboration of 121 worldwide countries with HUMS, it can be said that the university has a reasonable international collaboration with other countries. However, the collaboration with Asian and Middle-eastern countries needs to be emphasized. In line with the findings by Dwivedi (2017) for Banaras Hindu University, Sweileh et al. (2014) for Najah National University, and Maharana and Sethi (2013) for Sambalpur University, we found that HUMS's researchers had the highest collaboration with the USA's authors.

More than 50 percent of HUMS papers were authored by top 20 highly-productive authors. This result reminds us of the Pareto Principle or 80/20 law (Crawford, 2001).

Researchers in HUMS published their papers in 160 journals, no one in Q1. In addition, 8 journals out of top 10 publishing journals were from Iran. This is in accordance with the findings of study by Ahmed et al. (2010) that showed that the most favorable journal for Al-Jouf University's authors was a journal in Q3, i.e. the International Medical Journal. Therefore, researchers in developing countries tend to publish in low-level journals and policy-maker should consider and facilitate their attitude to publishing in high-level Q1 journals.

All highly-cited papers of HUMS were published in Q1 journals, such as New England Journal of Medicine, the Lancet, the Science and so on. As a result, researchers who want to be highlycited are recommended to publish in high-level and famous journals.

Term clustering of HUMS papers showed that the researchers in the university considered important medical fields and subfields ranging from epidemiological to microbiological studies. However, some subfield needs to be emphasized, including among others lifestyle medicine, traditional medicine, medical informetrics and local cancer research.

This study can be a pattern for studying and visualizing the bibliometric indicators of other universities and research institutions worldwide. In addition, policy-makers in HUMS can use the finding for better future policy-making for its more scientific development.

\section{Acknowledgments}

The study was funded by Vice-chancellor for Research and Technology, Hamadan University of Medical Sciences (No.9708224885). 


\section{References}

Ackermann, E. (2005). Bibliometrics of a controversial scientific literature: polywater research, 19621974. Scientometrics, 63 (2), 189-208.

Ahmed, A., \& Al-Reyaee, S. (2019). Bibliometric analysis of research publications of Al-Jouf University, Saudi Arabia during the Year 2006-2017. Library Philosophy and Practice, 2019 (2467), 1-9.

Archambault, E., Cote, G. and Michaud, B. (2008). Potential for scientific collaboration between Canada and Nordic countries 1998-2003 Denmark -Finland - Iceland - Norway - Sweden. Retrieved September 24, 2019, from http://www.sciencemetrix.com/pdf/SM_2005_004_ITC_Canada_Nordic_Countries_Collaboration.pdf.

Atayero, A. A., Popoola, S. I., Egeonu, J., \& Oludayo, O. (2018). Citation analytics: Data exploration and comparative analyses of CiteScores of Open Access and Subscription-Based publications indexed in Scopus (2014-2016). Data in brief, 19, 198-213.

Bakri, A., \& Willett, P. (2017). The malaysian journal of library and information science 2001-2006: A bibliometric study. Malaysian Journal of Library \& Information Science, 13 (1), 103-116.

Batooli, Z., Ravandi, S. N., \& Bidgoli, M. S. (2016). Evaluation of scientific outputs of Kashan university of medical sciences in scopus citation database based on Scopus, ResearchGate, and Mendeley scientometric measures. Electronic physician, 8 (2), 2048.

Bueno-Aguilera, F., Jiménez-Contreras, E., Lucena-Martín, C., \& Pulgar-Encinas, R. (2016). Dental research in Spain. A bibliometric analysis on subjects, authors and institutions (1993-2012). Medicina Oral, Patologia Oral Y Cirugia Bucal, 21 (2), e142.

Chan, K. C., Seow, G. S., \& Tam, K. (2009). Ranking accounting journals using dissertation citation analysis: A research note. Accounting, Organizations and Society, 34 (6-7), 875-885.

Chuang, K. Y., Chuang, Y. C., Ho, M., \& Ho, Y. S. (2011). Bibliometric analysis of public health research in Africa: The overall trend and regional comparisons. South African Journal of Science, 107 (5-6), 54-59.

Corrales-Reyes, I. E., Corrales, I. E., Reyes, J. J., \& Fornaris, Y. (2016). Bibliometric analysis of the Journal of Oral Research: Period 2012-2015. Journal of Oral Research, 5 (5), 188-193.

Corrales-Reyes, I. E., Fornaris-Cedeño, Y., Dorta-Contreras, A. J., Mejia, C. R., Pacheco-Mendoza, J., \& Arencibia-Jorge, R. (2019). Cuban Scientific Production on Diabetes, 2000-2017: Peerreviewed Publications, Collaboration and Impact. MEDICC review, 21, 17-25.

Crawford, W. (2001). Exceptional institutions: libraries and the Pareto principle. American Libraries, 32 (6), $72-74$.

Da Luz, M. P., Marques-Portella, C., Mendlowicz, M., Gleiser, S., Coutinho, E. S. F., \& Figueira, I. (2008). Institutional h-index: The performance of a new metric in the evaluation of Brazilian Psychiatric Post-graduation Programs. Scientometrics, 77(2), 361-368. 
Darmadji, A., Prasojo, L. D., Kusumaningrum, F. A., \& Andriansyah, Y. (2018). Research productivity and international collaboration of top Indonesian universities. Current Science, 115(4), 653-658.

De Oliveira, A.O., Oliveira, H.L.S., Gomes, C.F.S., \& Ribeiro, P.C.C. (2019). Quantitative analysis of RFID' publications from 2006 to 2016. International Journal of Information Management, 48, 185-192.

Dwivedi, S. (2017). Publications of Banaras Hindu University during 1989-2016: A three-dimensional Bibliometric Study. DESIDOC Journal of Library \& Information Technology, 37 (6), 403-409.

Falagas, M. E., Pitsouni, E. I., Malietzis, G. A., \& Pappas, G. (2008). Comparison of PubMed, Scopus, web of science, and Google scholar: strengths and weaknesses. The FASEB journal, 22 (2), 338342.

Fiala, D., \& Ho, Y. S. (2017). Twenty years of Czech science: A bibliometric analysis. Malaysian Journal of Library \& Information Science, 20 (2).

Gaviria-Marin, M., Merigo, J. M., \& Popa, S. (2018). Twenty years of the Journal of Knowledge Management: A bibliometric analysis. Journal of Knowledge Management, 22 (8), 1655-1687.

Haq, I. (2017). Research productivity at King Saud bin Abdul Aziz University for health sciences, Kingdom of Saudi Arabia: A bibliometric appraisal. Journal of Rawalpindi Medical College, 21 (2), 182-186.

Ho, T. M., Nguyen, H. V., Vuong, T. T., Dam, Q. M., Pham, H. H., \& Vuong, Q. H. (2017). Exploring Vietnamese co-authorship patterns in social sciences with basic network measures of 2008-2017 Scopus data. F1000Research, 6. Article 1559.

Huamaní, C., Romaní, F., González-Alcaide, G., Mejia, M. O., Ramos, J. M., Espinoza, M., \& Cabezas, C. (2014). South American collaboration in scientific publications on leishmaniasis: bibliometric analysis in SCOPUS (2000-2011). Revista do Instituto de Medicina Tropical de São Paulo, 56 (5), 381-390.

Hulme, E. W. (1923). Statistical bibliography in relation to the growth of modern civilization. Cambridge University Press, London.

HUMS (2019). Hamadan University of Medical Sciences. Retrieved September 24, 2019, from http://www.umsha.ac.ir

Hussain, A., Fatima, N., \& Kumar, D. (2011). Bibliometric analysis of the Electronic Library journal. Webology, 8 (1), Article 87. Retrieved September 24, 2019, from http://www.webology.org/2011/v8n1/a87.html

Jacobsson, S. (1997). Sweden's Technological System for Electronics and Computer Technology. In Technological systems and industrial dynamics (pp. 61-92). Springer, Boston, MA.

Jiang, B. J., Tan, X. D., Robinson, P., Liu, M., \& Di, J. (2014). Bibliometrics analysis of the scientific publication of the provincial capital cities CDC in China. Journal of Advances in Medicine and Medical Research. 4 (1), 529-539. 
Kahn, M. (2011). A bibliometric analysis of South Africa's scientific outputs: Some trends and implications. South African Journal of Science, 107 (1-2), 1-6.

Kamdem, J. P., Duarte, A. E., Lima, K. R. R., Rocha, J. B. T., Hassan, W., Barros, L. M., \& Tsopmo, A. (2019). Research trends in food chemistry: A bibliometric review of its 40 years anniversary (1976-2016). Food chemistry. 294, 448-457.

Kannan, P., \& Thanuskodi, S. (2019). Bibliometric analysis of library philosophy and practice: A study based on Scopus Database. Library Philosophy and Practice, 2019 (2300), 1-13.

Kazerani, M., Davoudian, A., Zayeri, F., \& Soori, H. (2017). Assessing abstracts of Iranian systematic reviews and metaanalysis indexed in WOS and Scopus using PRISMA. Medical journal of the Islamic Republic of Iran, 31, 18.

Krauskopf, E. (2018). A bibiliometric analysis of the Journal of Infection and Public Health: 20082016. Journal of Infection and Public Health, 11 (2), 224-229.

Kulkarni, A.V., Aziz, B., Shams, I. and Busse, J.W. (2009), Comparisons of citations in Web of Science, Scopus, and Google Scholar for articles published in general medical journals, JAMA, 302(10), 1092-1096.

Kulkarni, A. V., Aziz, B., Shams, I., \& Busse, J. W. (2009). Comparisons of citations in Web of Science, Scopus, and Google Scholar for articles published in general medical journals. JAMA, 302 (10), 1092-1096.

Laengle, S., Merigó, J. M., Miranda, J., Słowiński, R., Bomze, I., Borgonovo, E., \& Teunter, R. (2017). Forty years of the European Journal of Operational Research: A bibliometric overview. European Journal of Operational Research, 262 (3), 803-816.

Landström, H., Harirchi, G., \& Åström, F. (2012). Entrepreneurship: Exploring the knowledge base. Research Policy, 41(7), 1154-1181.

Layus, P., \& Kah, P. (2015). Bibliometric study of welding scientific publications by big data analysis. International Journal of Mechanical Engineering and Applications, 3 (5), 94-102.

Lian, Y., \& Wang, L. (2018). A bibliometric analysis of the papers on urban education. EURASIA Journal of Mathematics, Science and Technology Education, 14 (7), 2857-2866.

Li, Y., Liu, C., Zhang, J., \& Li, F. (2018). A bibliometric analysis and visualization of environmental damage research from 2000 to 2018. In IOP Conference Series: Earth and Environmental Science (Vol. 170, No. 3, p. 032079). IOP Publishing.

Maharana, R. K., \& Sethi, B. B. (2013). A bibliometric analysis of the research output of Sambalpur University's publication in ISI Web of Science during 2007-11. Library Philosophy and Practice, 2013 (926), 1-13.

Martínez-López, F. J., Merigó, J. M., Valenzuela-Fernández, L., \& Nicolás, C. (2018). Fifty years of the European Journal of Marketing: a bibliometric analysis. European Journal of Marketing, 52 (1/2), 439-468. 
Merigó, J. M., Gil-Lafuente, A. M., \& Yager, R. R. (2015). An overview of fuzzy research with bibliometric indicators. Applied Soft Computing, 27, 420-433.

Milojevic, S. (2009). Big science, nano science? mapping the evolution and socio-cognitive structure of nanoscience/nanotechnology using mixed methods. PhD Dissertation, University of California, Los Angeles.

Mokhtari, H., Roumiyani, A., \& Saberi, M.K. (2019). Bibliometric analysis and visualization of the Journal of Artificial Societies and Social Simulation (JASSS) between 2000 and 2018. Webology, 16 (1). 166-183.

Mohsen, M.A., Fu, H.Z. \& Ho, Y.S. (2017). A Bibliometric Analysis of linguistics publications in the Web of Science. Journal of Scientometric Research, 6 (2), 109-18.

Monge-Nájera, J., \& Ho, Y. S. (2017). Bibliometrics of Nicaraguan publications in the Science Citation Index Expanded. Revista de Biología Tropical, 65 (2), 643-655.

Monge-Nájera, J., \& Ho, Y. S. (2018). Guatemala articles in the Science Citation Index Expanded: bibliometry of subjects, collaboration, institutions and authors. Revista de Biología Tropical, 66 (1), 312-320.

Mousavi Chalak, A., Yaminfirooz, M., \& Riahi, A. (2018). Quantitative and qualitative evaluation of Islamic Republic of Iran's scientific productions indexed in Scopus in the field of nursing during 2000-2016. Qom University of Medical Sciences Journal, 12 (4), 61-71.

Nafade, V., Nash, M., Huddart, S., Pande, T., Gebreselassie, N., Lienhardt, C., \& Pai, M. (2018). A bibliometric analysis of tuberculosis research, 2007-2016. PloS one, 13 (6), e0199706.

Noyons, E.C.M. (1999), Bibliometric mapping as a science policy and research management tool. Doctoral dissertation, Centrum voor Wetenschaps-en, Faculty of Science, Leiden University.

Noyons, C. M. (2004). Science maps within a science policy context. In Handbook of quantitative science and technology research (pp. 237-255). Springer, Dordrecht.

Osei Boamah, P., \& Ho, Y. S. (2018). Bibliometric analysis of Ghana publications in the Science Citation Index Expanded. Revista de Biología Tropical, 66 (1), 106-121.

Özkoze, H., \& Gencer, C. T. (2017). Bibliometric analysis and mapping of management information systems field. Gazi University Journal of Science, 30 (4), 356-371.

Pritchard, A. (1969). Statistical bibliography or bibliometrics. Journal of Documentation, 25 (4), 348349.

Rojas-Sola, J. I., \& Jorda-Albinana, B. (2010). Bibliometric analysis of Venezoelan scientific publications un the ecology category of Web of Science database (1997-2008). Interciencia, 35 (8), 619-623.

Romanelli, J. P., Fujimoto, J. T., Ferreira, M. D., \& Milanez, D. H. (2018). Assessing ecological restoration as a research topic using bibliometric indicators. Ecological engineering, 120, 311-320. 
Rondanelli, M., Perna, S., Peroni, G. \& Guido, D. (2016). A bibliometric study of scientific literature in Scopus on botanicals for treatment of androgenetic alopecia. Journal of Cosmetic Dermatology, 15 (2), 120-130.

Sabah, F., Hassan, S. U., Muazzam, A., Iqbal, S., Soroya, S. H., \& Sarwar, R. (2019). Scientific collaboration networks in Pakistan and their impact on institutional research performance: A case study based on Scopus publications. Library Hi Tech, 37 (1), 19-29.

Sachini, E., Malliou, N., Karampekios, N., \& Karaiskos, D. (2015). Greek scientific publications 19982012: A Bibliometric Analysis of Greek Publications in International Scientific JournalsScopus. Athens: National Documentation Center.

Saravanan, C.G. (2012). Bibliometric analysis of the scientific publications of the Western Ghats. In: Proceedings of the UGCSAP National Seminar on Scientometrics and Informetrics, 9-10 March, 2012 held at Annamalai University, Annamalai Nagar, Chidambaram (pp. 215-220).

Sa'ed, H. Z., Al-Jabi, S. W., Sweileh, W. M., \& Awang, R. (2014). A Scopus-based examination of tobacco use publications in Middle Eastern Arab countries during the period 2003-2012. Harm Reduction Journal, 11 (1), 14.

Şenel, E., \& Demir, E. (2018). Bibliometric and scientometric analysis of the articles published in the journal of religion and health between 1975 and 2016. Journal of Religion and Health, 57(4), 1473-1482.

Sengupta, I. N. (1992). Bibliometrics, informetrics, scientometrics and librametrics: An overview. Libri, $42(2), 75-98$.

Siwach, A. K., \& Kumar, S. (2015). Bibliometric analysis of research publications of Maharshi Dayanand University (Rohtak) during 2000-2013. DESIDOC Journal of Library \& Information Technology, 35 (1).

Sweileh, W. M., Zyoud, S. E. H., Al-Khalil, S., Al-Jabi, S. W., \& Sawalha, A. F. (2014). Assessing the scientific research productivity of the Palestinian higher education institutions: A case study at AnNajah National University, Palestine. SAGE Open, 4 (3).

Synnestvedt and Chen, C. (2005). Design and evaluation of the tightly coupled perceptual-cognitive tasks in knowledge domain visualization. In Proceedings of the $11^{\text {th }}$ International Conference on Human-Computer Interaction (HCI International 2005). New York: ACM., M.B.

Taga, V., Oliveira Inomata, D., Rodrigues Vaz, C., Uriona Maldonado, M., \& Varvakis, G. (2017). Bibliometric analysis of the scientific production of the information architecture related to libraries. Biblios, (67), 1-15.

Tang, M., Liao, H., \& Su, S. F. (2018). A bibliometric overview and visualization of the International Journal of Fuzzy Systems between 2007 and 2017. International Journal of Fuzzy Systems, 20 (5), 1403-1422.

Tang, M., Liao, H., Wan, Z., Herrera-Viedma, E., \& Rosen, M. (2018). Ten years of sustainability (2009 to 2018): A bibliometric overview. Sustainability, 10 (5), 1655. 
Tsafe, A. G., Chiya, U., \& Aminu, B. A. (2016). Scholarly publications of librarians in universities in Nigeria: 2000-2012 - A bibliometric analysis. Library Philosophy and Practice, 2016 (1394),1-24.

Tur-Porcar, A., Mas-Tur, A., Merigó, J. M., Roig-Tierno, N., \& Watt, J. (2018). A bibliometric history of the journal of psychology between 1936 and 2015. The Journal of psychology, 152 (4), 199-225.

Uddin, A., Singh, V. K., Pinto, D., \& Olmos, I. (2015). Scientometric mapping of computer science research in Mexico. Scientometrics, 105 (1), 97-114.

Van Eck, N., \& Waltman, L. (2009). Software survey: VOSviewer, a computer program for bibliometric mapping. Scientometrics, 84 (2), 523-538.

Van Eck, N., Waltman, L., Noyons, E. \& Buter, R. (2010). Automatic term identification for bibliometric mapping, Scientometrics, 82 (3), 581-596.

Yessirkepov, M., Nurmashev, B., \& Anartayeva, M. (2015). A Scopus-based analysis of publication activity in Kazakhstan from 2010 to 2015: Positive trends, concerns, and possible solutions. Journal of Korean Medical Science, 30 (12), 1915-1919.

Zarei, M., Bagheri-Saweh, M. I., Rasolabadi, M., Vakili, R., Seidi, J., Kalhor, M. M., \& Gharib, A. (2017). Breast cancer research in Iran: A scientometric analysis of publications output from 1991 to 2015 in Scopus. Electronic physician, 9 (2), 3816-3822.

Zhai, X., Zhao, J., Wang, Y., Wei, X., Li, G., Yang, Y., \& Li, M. (2018). Bibliometric Analysis of Global Scientific Research on lncRNA: A Swiftly Expanding Trend. BioMed Research International, 2018. Article ID 7625078.

Zhang, C. C., Zheng, X., Su, C. H., Huang, H., Yan, F. R., Pan, X. J., \& Jin, Z. Z. (2017). A bibliometric study of the Journal of School Health: 1965-2014. Chinese Nursing Research, 4 (2), 75-83.

Zyoud, S. E. H., Al-Jabi, S. W., Sweileh, W. M., \& Awang, R. (2014). A bibliometric analysis of toxicology research productivity in Middle Eastern Arab countries during a 10-year period (20032012). Health Research Policy and Systems, 12 (4), 4.

Zyoud, S.H., Al-Jabi, S.W., Sweileh, W.M. \& Waring, W.S. (2015). Scientific research related to calcium channel blockers poisoning: Bibliometric analysis in Scopus, 1968-2012. Human \& Experimental Toxicology, 34 (11), 1162-1170.

\section{Bibliographic information of this paper for citing:}

Mokhtari, Heidar; Mirezati, Seyedeh Zahra; Saberi, Mohammad Karim; Fazli, Farzaneh, \& Kharabati-Neshin, Mohammad (2019). "A bibliometric analysis and visualization of the scientific publications of universities: A study of Hamadan University of Medical Sciences during 1992-2018", Webology, 16(2), Article 198. Available at: http://www.webology.org/2019/v16n2/a198.pdf

Copyright (C) 2019, Heidar Mokhtari, Seyedeh Zahra Mirezati, Mohammad Karim Saberi, Farzaneh Fazli and Mohammad Kharabati-Neshin. 